\title{
Bicondylaris tibia plató törések kettős lemezelése
}

\author{
DR. CSONKA ÁKOS, DR. GÁRGYÁN ISTVÁN, DR. BOA KRISTÓF, \\ DR. SÁDT ZOLTÁN, DR. VARGA ENDRE
}

\section{ÖSSZEFOGLALÁS}

A bicondylaris tibia plató törések kezelésében az anatómiai formát követő, alacsony profilú, szögstabil lemezek bevezetése nagy elörelépést jelentett. Ezek az implantátumok bizonyos mértékig rugalmasak, és amikor a beteg ezt a "csont-szögstabil rendszert” terheli, az enyhén elasztikusan deformálódik, ahelyett, hogy lazulás következne be a csont-csavar kapcsolódás helyén. Sokáig azt feltételeztük, hogy a lateralisan felhelyezett szögstabil lemezek önállóan alkalmazhatók a 41 AO C2-3, illetve Schatzker V-VI. típusú töréseknél. A CT vizsgálatok alapján azonban tudjuk, hogy a medialis condylus posteromedialis, coronalis síkú törése nagyon gyakori, és ez a hátsó törtdarab distal-posterior irányba dislocálódhat. A medialis femur condylus követi a dislocálódott fragmentumot, ezért ha a fragmentum reponálatlan, a térd varus helyzetbe kerül és a medialis condylus posterior irányban subluxált marad. Ennek rögzítése alapvető fontosságú a stabilitás helyreállítása miatt. A lateralis szögstabil lemezek azonban ezt nem tudják biztosítani. Ezen törések és a darabos, instabil medialis törések kiegészítő rögzítésére egy posteromedialisan felhelyezett antiglide lemezt használunk, ezzel növelve a medialis oldal stabilitását. Eredményeink és az irodalmi adatok alapján javasoljuk a bicondylaris tibia plató törések ellátására a preoperativ CT elvégzését, és a lateralisan felhelyezett szögstabil lemez mellett a posteromedialis antiglide lemez alkalmazását. Ezen módszer megakadályozza a törések másodlagos elmozdulását és nem növeli az infekciós szövődmények számát.

\section{Kulcsszavak: $\quad$ Lemezelés; Térdsérülés; Tibia törés;}

\section{Á. Csonka, I. Gárgyán, K. Boa, Z. Sádt, E. Varga: Double plating of bicondylar tibial plateau fractures}

Introduction of anatomically shaped, low-profile, angular stable plates have been a big step forward in the treatment of bicondylar tibial plateau fractures. These implants provide a certain degree of elasticity, thus when the patient exerts load on the construct of bone and the angular stable system, mild elastic deformation presents instead of loosening at the bone-screw interface. It has been long presumed that angular stable plates placed on the lateral side can be used on their own in the treatment of AO 41 C2-3 and Schatzker type V and VI fractures. However, CT studies demonstrated that the posteromedial, coronal plane fracture of the medial condyle is very common, and this posterior fragment can be distally and posteriorly displaced. The medial femoral condyle "follows" this displaced fragment, thus the knee develops varus deformity and the medial condyle remains posteriorly subluxed. Because of this fact, the fixation of this fragment is crucial to restore stability. However, laterally placed angular stable plates cannot provide this. We use posteromedial buttress plates in cases of these type of fractures and medial unstable, multifragmentary fractures as well, increasing the stability of the medial side. According to our results and to literature data, we suggest preoperative CT examination and the use of posteromedial antiglide plates besides lateral angular stable plates in the treatment of bicondylar tibial plateau fractures. This method prevents secondary displacement and does not increase the rate of infectious complications.

Keywords: $\quad$ Bone plates; Knee joint - Diagnostic imaging/Surgery; Tibial fractures - Diagnostic imaging/Surgery; 


\section{BEVEZETÉS}

A tibia proximalis vég töréseinek előfordulása fokozatosan növekszik. Ezek a törések az összes törés 1\%-át teszik ki (20). Fiataloknál általában nagy energiájú trauma következménye, időseknél az osteoporoticus csontot komprimáló erők hatására jöhet létre törés. Az irodalmi adatok szerint a nemek közti megoszlás szempontjából a férfiaknál kissé gyakoribb az előfordulásuk (18). A többszörös bicondylaris tibia törések kezelése nagy kihívást jelent. Nélkülözhetetlen a részletesen kidolgozott kezelési terv felállítása. Fontos a fizikális státusz rögzítése (lágyrészek állapota, keringés, beidegzés). A standard AP és oldalirányú röntgenfelvételek mellett a kiegészítő, ferde felvételek segíthetnek a törés jobb megítélésében. Ezen kívül CT (3D rekonstrukció) vizsgálat, és sok esetben MRI elkészítése is javasolt a társult ízületi sérülések kimutatása miatt $(13,18,11)$. A képalkotó diagnosztika pontosabbá válása új szemléletet hozott a törések ellátásában is. Ez alapján minden esetben CT és 3D rekonstrukció felvételek segítségével célszerü elemezni a proximalis tibia töréseit, figyelembe véve a „három-oszlop" elméletet $(8,9)$.

A törés klasszifikációját a megfelelő műtéti terv felállítása követi. A dislocálódott condylusok reponálása, az ízfelszínek kongruenciájának helyreállítása, az imprimálódott ízületi fragmentumok kiemelése és a végtag optimális anatómiai tengelyének beállítása
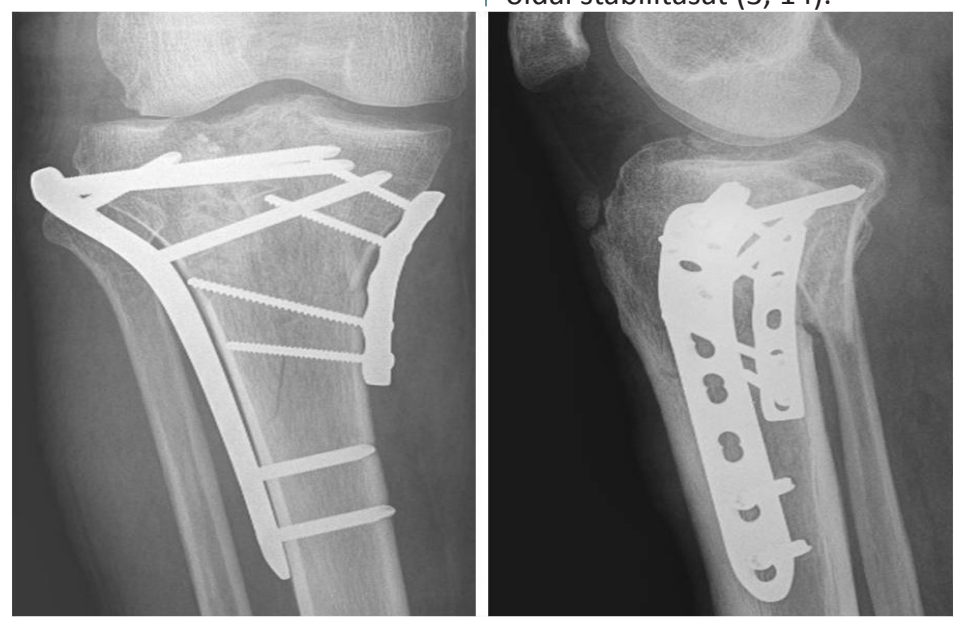

1. ábra Proximalis tibia plató törés kettős lemezelése során alkalmazott Proximal Lateral Tibia LISS és posteromedialis antiglide lemez. A KF LCDC lemez nincs ideális pozícióban, a tibia plató szélesebb és néhány fokos varus tengelyállás van. nehéz feladat. A mútét elvégzésének időpontját alapvetően a lágyrészek állapota határozza meg. A többlépcsős ellátás és a minimál invazív technikák alkalmazása jelentős mértékben csökkenti a lágyrészekkel összefüggésbe hozható szövődmények (infekció, sebszétválás, szöveti nekrózis) arányát. A különböző irodalmi adatok szerint ezek aránya 5-10\% között változhat $(2,19)$.

Mindezek mellett a korai rehabilitáció, az irányított gyógytorna nélkülözhetetlen a jó funkcionális eredmények eléréséhez. Sajnos, még az adekvát mútéti ellátás és gyógytorna ellenére is az esetek 10-58\%-ban szembesülünk poszttraumás arthrosis kialakulásával, amelynek okai elsősorban a fel nem ismert és ellátatlan ízületi sérülések lehetnek (20). A kezelési mód megválasztása ma is vita tárgyát képezi (5).

A hazai irodalomban több cikk is foglalkozott a tibiafej törések mútéti ellátásával $(1,10$, 16). A szögstabil implantátumok megjelenése lehetővé tette a minimál invazív technikák alkalmazását, illetve az unilateralis lemez felhelyezést (6). Azonban ezek alkalmazása ellenére a kizárólag lateralis oldalra felhelyezett lemez esetén 13\%-ban számíthatunk a törés másodlagos dislocatiójára (13). Ennek a szövődménynek a kivédésére a 41 AO C2-3 törések esetében kiegészítő rögzítésre egy posteromedialisan felhelyezett antiglide lemezt használunk (1. ábra), ezzel növelve a medialis oldal stabilitását $(3,14)$. 


\section{ANYAG ÉS MÓDSZER}

Klinikánkon prospektív vizsgálatot folytattunk a 41 AO C2-3 típusú bicondylaris tibia plató törések ellátása és a késői szövődmények felismerését illetően. 2005-2011 között 15 esetben alkalmaztunk a Proximal Lateral Tibia LISS ${ }^{\circledR}$ (J\&J DePuy Synthes) mellett posteromedialisan felhelyezett antiglide lemezt. A mútéti tervezéséhez a röntgenfelvételek mellett minden esetben $\mathrm{CT} / 3 \mathrm{D}$ rekonstrukció vizsgálatot is végeztünk. A képalkotó diagnosztika után a törés jellegétől és a lágyrész viszonyoktól függően primeren a törést és a térdízületet áthidaló unilateralis fixateur externe felhelyezése történt. A 41 AO C2-3 töréseknél fennáll a compartement szindróma veszélye, ezért a lágyrészek állapotának rendeződése után (5-10 nap) került sor a végleges mútéti ellátásra. A mútét utáni röntgenfelvételeken elemeztük a repozíció eredményességét, majd a 6., 12., 16., 26. és 52 . héten készült röntgenfelvételeken tanulmányoztuk az esetleges redislocatiót, valamint a törésgyógyulás mértékét. A 6. héttól részterhelést, majd a 12. héttől a fájdalomhatárig történő teljes terhelést engedélyeztünk betegeinknek. Vizsgáltuk a sérült ízület mozgástartományát. Az eredményeket a Knee Society Score és Functional Score (KSS+FS) szerint értékeltük.

\section{MEGFIGYELÉSEK}

A vizsgált időszakban 15 beteget (8 férfi és 7 nő) kezeltünk osztályunkon 41 AO C2-3 típusú bicondylaris tibia plató törés miatt kettős lemezeléssel. A betegek átlagéletkora 68 év volt. Mind a 15 betegnél a 16. héten jó ütemű törés konszolidációt láttunk, a 26. héten történt kontroll vizsgálatnál pedig már mindegyik törés teljes átépülést mutatott. Egy betegünknél újabb mútétet kellett végezni a korai posztoperatív szakban redislocatio miatt, az összes többi esetben másodlagos redislocatiót nem észleltünk. Három esetben alkalmaztunk autológ csontpótlást csípőlapátból vett spongiosával, két esetben pedig szintetikus csontpótló anyaggal $\left(\mathrm{Chronos}^{\circledR}\right.$, J\&J DePuy Synthes) töltöttük ki a visszamaradt üreget. Egy betegnél a posztoperatív 16. héten egy spongiosa csavart távolítottunk el, mivel az nyomási diszkomfortot okozott. Hat betegnél láttunk a 26. héten periarticularis meszesedést, ami jelentős, 40\%-os előfordulást jelent. Az átlagos ROM (Range Of Motion) az érintett térdízületben $98,3^{\circ}$ volt a sérülés után fél évvel. Infekciós szövődményt, compartement szindrómát nem észleltünk. Egy betegnél alakult ki az érintett végtagon mélyvénás trombózis az LMWH terápia befejezését követően. A hat hónapos kontroll alkalmával a KSS+FS alapján 9 betegünk a jó (KSS=75, FS=90), míg 6 betegünk az elfogadható csoportba sorolható (KSS=65, $\mathrm{FS}=90$ ).

\section{ESETISMERTETÉS}

43 éves férfibeteg, nagy energiájú traumára szenvedte el bal oldali proximalis tibia 41 AO C3 törését. A primer röntgenfelvételeken jól látható a lateralis tibia condylus multifragmentalis, impaktálódott törése, illetve medialisan a metaphysis érintettsége (2. ábra). A részletes elemzéshez, valamint a mútéti terv felállításához $\mathrm{CT}$ vizsgálatot végeztünk. A 3D rekonstrukciós CT felvételeken jól látható a lateralis condylus törése mellett a medialis condylus hátsó részének törése is (3. ábra). Megfelelő előkészítés után, tervezett időpontban, háton fekvésben, kettős feltárásból végeztünk mútétet. A posteromedialis tibia condylust hagyományos $L$ alakú lemezzel stabilizáltuk, míg a lateralis felszínre titán szögstabil lemezt helyeztünk (4. ábra). Érdemes megjegyezni, hogy az esetek többségében először a posteromedialis lemezt célszerű felhelyezni. A posztoperatív időszak zavartalanul telt. Fájdalomcsillapítás mellett, gyógytornász irányításával korai mobilizáció történt, az operált végtag tehermentesítése mellett, limitált mozgástartományban (0-30 fok), térdrögzítő viselésével. A 6. hét után $15 \mathrm{~kg}$-os terheléssel közlekedett, a térd mozgástartományát kéthetenként 30 fokkal növeltük. A beteg a sérülést követő 12 . héten végtagját teljes testsúllyal terhelve, segédeszköz nélkül közlekedett. A féléves kontroll röntgenfelvételeken a törés jó ütemú átépülése látható, azonban a lateralis condylus ízfelszínének inkongruenciája, illetve a medialis condylusnál a bőrt előemelő 6.5 mm-es spongiosa csavar is látható (5. ábra). Az 1 éves kontrollvizsgálat alkalmával segédeszköz nélkül, operált végtagját teljes testsúllyal terhelve, minimális sántítás mellett közlekedett. 
Térde időnként, főleg nagyobb megterhelés után megduzzadt, illetve időjárás változásra

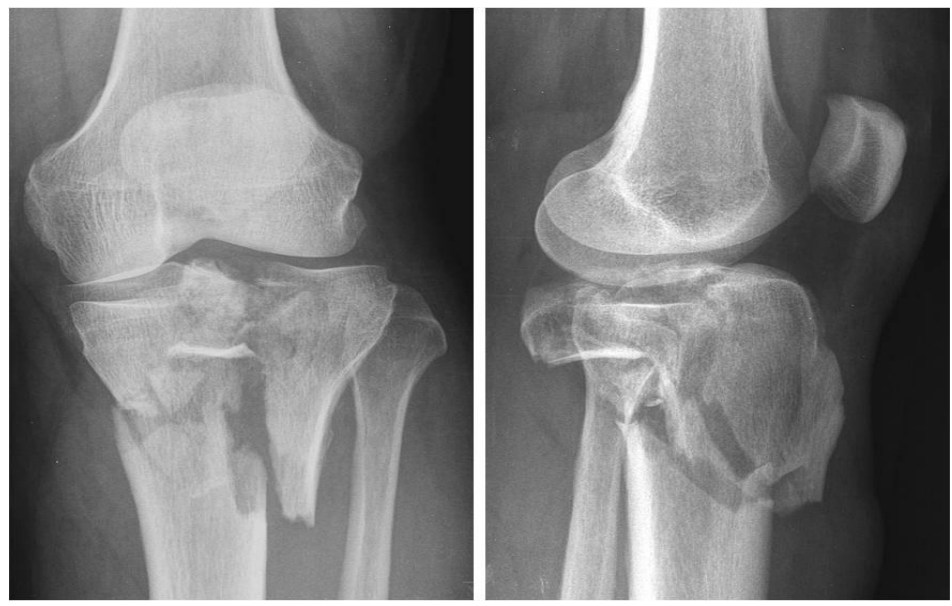

2. ábra Preoperativ röntgenfelvétel, 41 AO C3 tibia plató törés
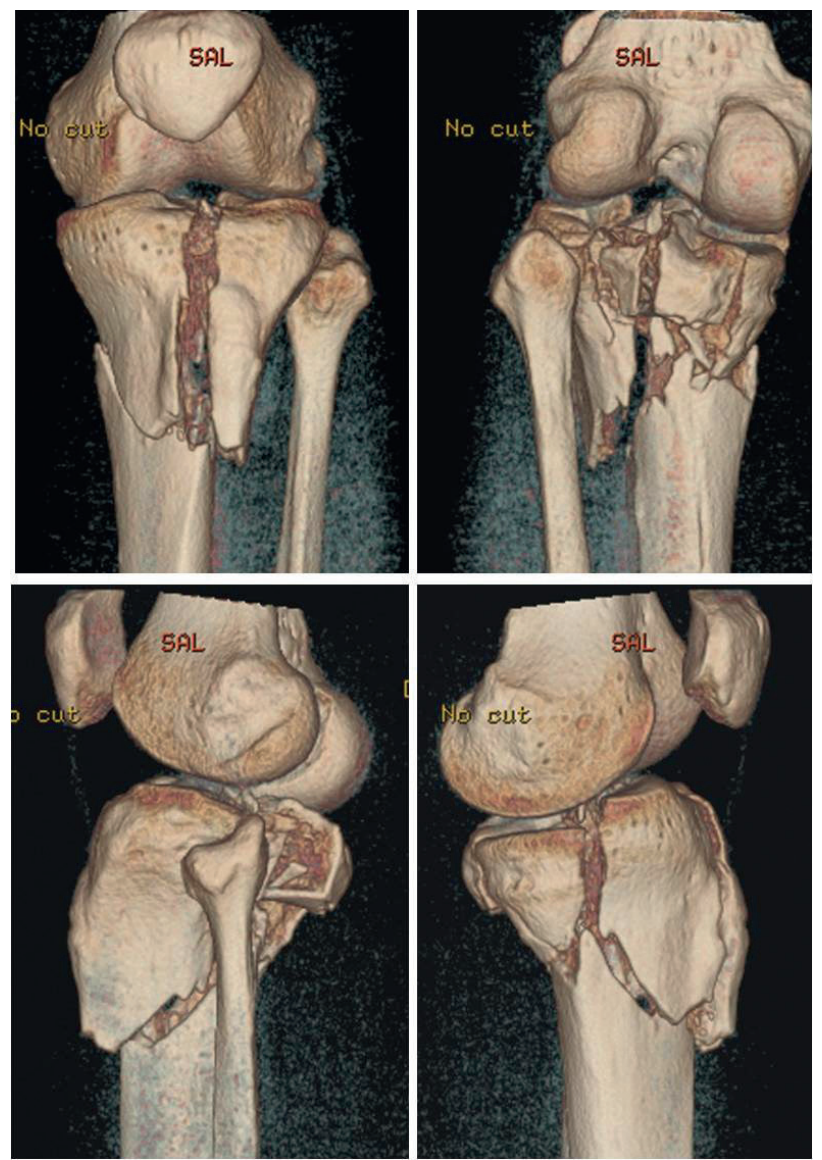

3. ábra Preoperativ 3D rekonstrukciós CT felvétel a mútéti terv felállitásához 


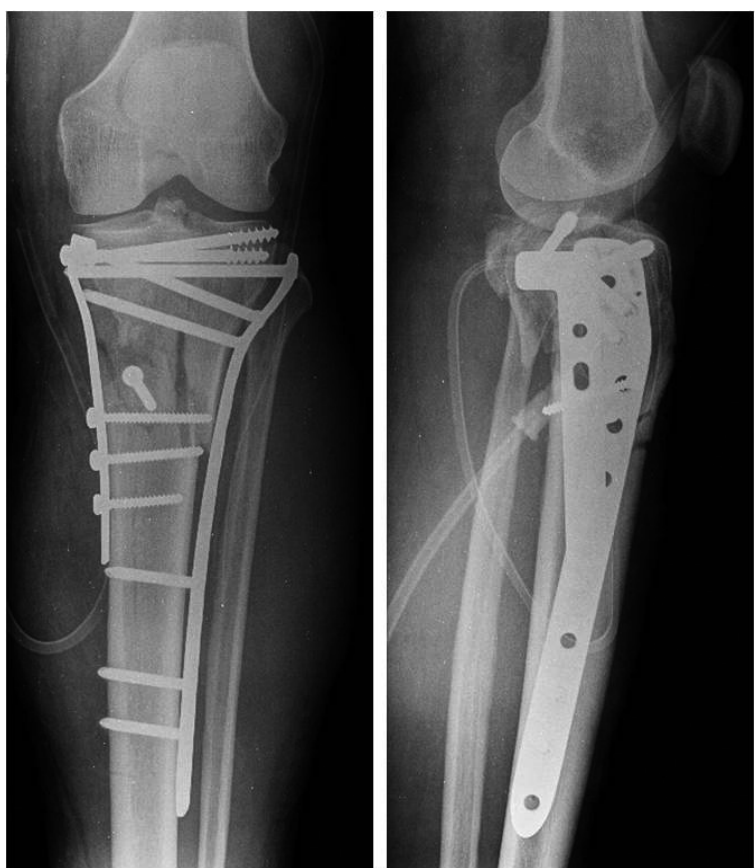

4. ábra Posztoperatív röntgenfelvétel, kétoldali lemezes osteosynthesis

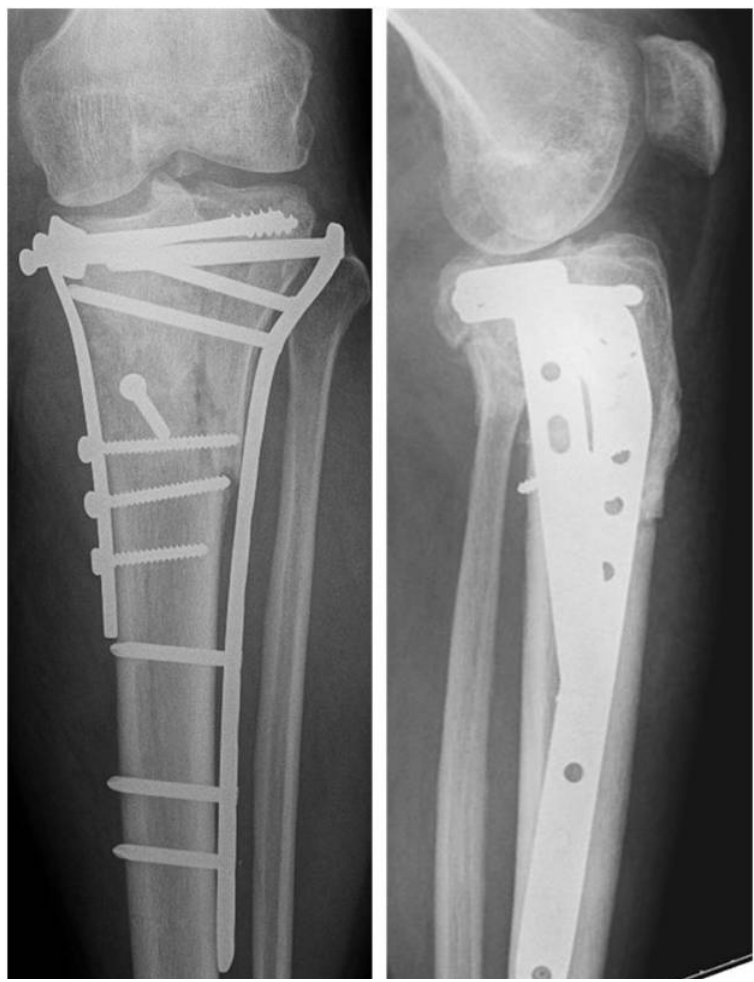

5. ábra Fél éves kontroll röntgenfelvétel, gyógyult törés 


\section{MEGBESZÉLÉS}

A bicondylaris tibia plató törések száma növekvő tendenciát mutat. Kezelésük nagy kihívást jelent a traumatológusok számára. A mútét tervezéséhez az alapos fizikális vizsgálat és hagyományos röntgenfelvételeken túl minden esetben a preoperatív CT felvételek elkészítése javasolt. Sohn és munkatársai 278 beteg CT felvételeit retrospektíve elemezve 84 esetben észleltek letört posteromedialis fragmentumot, ami a medialis tibia plató 1/3-át érintette (17). A szakirodalom javasolja az MRI elvégzését is, mivel a törések mellett nagyon sok esetben az intraarticularis képletek is sérülhetnek. Ezek a sérülések felelősek elsősorban a korai poszttraumás arthrosis kialakulásáért (11).

Széleskörű szakmai vita folyik a bicondylaris tibia plató törések ellátásáról. A fixateur externe-nel történő kezelés és a feltárással, lemezzel történő rögzítés egyaránt elfogadott módszerek (12). Ezen törések definitív mútéti ellátása sok esetben halasztottan történik, a lágyrészek állapotának rendeződése után (4). A szögstabil lemezek megjelenése előtt az ajánlott mútéti ellátás a kettős lemezelés volt a konvencionális lemezeket alkalmazva. Darabos törések esetén és főleg osteoporoticus csontban nagy volt a redislocatiók aránya, ezért az elmúlt 15 évben inkább az anatómiai szögstabil lemezeket részesítjük előnyben. A primeren felhelyezett fixateur externe, majd a halasztott módszerváltás, kétoldali feltárásból, kettős lemezzel történő törésrögzítés jelentősen, 8.4\%-ra csökkentette az infekciók és a redislocatiók előfordulási arányát (2). A törések ellátása során fontos a ligamentotaxis kihasználása disztraktor vagy fixateur externe alkalmazásával (15). Neogi és munkacsoportja végzett összehasonlító tanulmányt 61 beteg bevonásával, közel 5 éves időtartamot figyelembe véve, amely során az uni-, illetve bilateralisan felhelyezett lemezes osteosynthesiseket elemezték. Eredményeik alapján a bilateralisan felhelyezett lemezes rögzítéssel jobb hosszú távú eredmény érhető el (14).

Általánosságban kijelenthetjük, hogy a bicondylaris tibia plató törések egy része jól kezelhető csak lateralisan felhelyezett szögstabil lemezzel, ha nagy a medialis condylus darab és a metaphysis nem darabos. Ugyanakkor, a CT-n gyakran látható coronalis síkú medialis condylus törtdarab rendszerint kisméretű és megfelelő rögzítés nélkül $14 \%$ a valószínűsége a fragmentum másodlagos elmozdulásának, ha csak az unilateralis szögstabil lemezt alkalmazzuk. A 41 AO C2-3, illetve Schatzker V-VI. típusú törések esetén javasolt a laterálisan felhelyezett szögstabil lemez mellett a medialis támasztó vagy posteromedialis antiglide lemez alkalmazása. Természetesen a lágyrészek állapotára szigorúan tekintettel kell lenni, és megfelelő, kíméletes mútéti technikát kell alkalmazni $(7,21)$.

Szintetikus tibián végzett terheléses vizsgálatok azt mutatták, hogy a coronalis síkú törésre alkalmazott posteromedialis antiglide lemez akadályozta meg leginkább a fragmentum elcsúszását, összehasonlítva az anteroposterior húzócsavarral, az anteromedialis LC-DCP-vel és a laterális szögstabil lemezzel (22). Ezen módszer alkalmazása az irodalmi adatok és saját tapasztalataink alapján megakadályozza a törések másodlagos elmozdulását.

Beteganyagunkban ezen mútéti technika alkalmazása nem növelte az infekciós szövődmények számát. Hangsúlyozzuk, hogy minden bycondylaris tibia plató törött beteg ellátása nagyon gondos mútéti terv felállítása után történjen meg, a lágyrészek és a törés jellegének megfelelően megválasztva a mútét időpontját és az alkalmazott implantátumot. 


\section{IRODALOM}

1. Bárdos I., Detre Z., Fekete K., Tibiafej luxatiós törésének mútéti ellátása postero-lateralis támasztólemezzel Magyar Traumatológia Ortopédia Kézsebészet Plasztikai Sebészet, 1998. 41. 50-56.

2. Barei D. P., Nork S. E., Mills W. J., Henley M. B., Benirschke S. K.: Complications associated with internal fixation of highenergy bicondylar tibial plateau fractures utilizing a two-incision technique. J. Orthop. Trauma. 2004. 18. (10): 649-657. https://doi.org/10.1097/00005131-200411000-00001

3. Chang S. M., Hu S. J., Zhang Y. Q., Yao M. W., Ma Z., Wang X., Dargel J., Eysel P.: A surgical protocol for bicondylar four-quadrant tibial plateau fractures. Int. Orthop. 2014. 38. (12): 2559-2564. https://doi.ora/10.1007/s00264-014-2487-7

4. Cherney S., Gardner M. J.: Bicondylar tibial plateau fractures: assessing and treating the medial fragment. J. Knee Surg. 2014. 27. (1): 39-45. https://doi.ora/10.1055/s-0033-1363518

5. Conserva V., Vicenti G., Allegretti G., Filipponi M., Monno A., Picca G., Moretti B.: Retrospective review of tibial plateau fractures treated by two methods without staging. Injury. 2015. 46. (10): 1951-1956. https://doi.org/10.1016/i.injury.2015.07.018

6. Gosling T., Schandelmaier P., Muller M., Hankemeier S., Wagner M., Krettek C.: Single lateral locked screw plating of bicondylar tibial plateau fractures. Clin. Orthop. Relat. Res. 2005. 439. 207-214. https://doi.org/10.1097/00003086-200510000-00036

7. Lee M. H., Hsu C. J., Lin K. C., Renn J. H.: Comparison of outcome of unilateral locking plate and dual plating in the treatment of bicondylar tibial plateau fractures. J. Orthop. Surg. Res. 2014. 20. 9-62. https://doi.org/10.1186/s13018-014-0062-y

8. Lin K. C., Tarng Y. W., Lin G. Y., Yang S. W., Hsu C. J., Renn J. H.: Prone and direct posterior approach for management of posterior column tibial plateau fractures. Orthop. Traumatol. Surg. Res. 2015. 101. (4): 477-482. https://doi.org/10.1016/j.otsr.2014.12.021

9. Luo C. F., Sun H., Zhang B., Zeng B. F.: Three-column fixation for complex tibial plateau fractures. J. Orthop. Trauma. 2010. 24. (11): 683-692. https://doi.org/10.1097/BOT.0b013e3181d436f3

10. Manninger J., Salacz T., Fekete K.: Impressziós tibia condylus törés mozgásstabil szintézise módosított lemezzel. I. rész. Magy. Traumatol. Orthop. 1981. 24: 108-120.

11. Markhardt B. K., Gross J. M., Monu J. U.: Schatzker classification of tibial plateau fractures: use of CT and MR imaging improves assessment. Radiographics. 2009. 29. (2): 585-597. https://doi.org/10.1148/rg.292085078

12. Metcalfe D., Hickson C. J., McKee L., Griffin X. L.: External versus internal fixation for bicondylar tibial plateau fractures: systematic review and meta-analysis. J. Orthop. Traumatol. 2015. 16. (4): 275-285. https://doi.org/10.1007/s10195-015-0372-9

13. Musahl V., Tarkin I., Kobbe P., Tzioupis C., Siska P.A., Pape H.C.: New trends and techniques in open reduction and internal fixation of fractures of the tibial plateau. J. Bone Joint Surg. Br. 2009. 91. (4): 426-433. https://doi.org/10.1302/0301-620X.91B4.20966

14. Neogi D. S., Trikha V., Mishra K. K., Bandekar S. M., Yadav C. S.: Comparative study of single lateral locked plating versus double plating in type C bicondylar tibial plateau fractures. Indian J. Orthop. 2015. 49. (2): $193-198$. https://doi.org/10.4103/0019-5413.152478

15. Potocnik P., Acklin Y. P., Sommer C.: Operative strategy in postero-medial fracture-dislocation of the proximal tibia. Injury. 2011.42. (10): 1060-1065. https://doi.orq/10.1016/i.injury.2011.03.041

16. Salacz T., Manninger J., Fekete K.:Impressziós tibia törés mozgásstabil szintézise módosított lemezzel I. és II. rész. Magyar Traumatológia Ortopédia Kézsebészet Plasztikai Sebészet. 1982. 25: 243-255.

17. Sohn H. S., Yoon Y. C., Cho J. W., Cho W. T., Oh C. W., Oh J. K.: Incidence and fracture morphology of posterolateral fragments in lateral and bicondylar tibial plateau fractures. J. Orthop. Trauma. 2015. 29. (2): 91-97. https://doi.org/10.1097/BOT.0000000000000170

18. Thomas C., Athanasiov A., Wullschleger M., Schuetz M.: Current concepts in tibial plateau fractures. Acta Chir. Orthop. Traumatol. Cech. 2009. 76. (5): 363-373.

19. Valderrama-Molina C. O., Estrada-Castrillón M., Hincapie J. A., Lugo-Agudelo L. H.: Intra-and interobserver agreement on the Oestern and Tscherne classification of soft tissue injury in periarticular lower-limb closed fractures. Colomb. Med. (Cali). 2014. 45. (4): $173-178$.

20. van Dreumel R. L., van Wunnik B. P., Janssen L., Simons P. C., Janzing H. M.: Mid-to long-term functional outcome after open reduction and internal fixation of tibial plateau fractures. Injury. 2015. 46. (8): 1608-1612. https://doi.org/10.1016/j.injury.2015.05.035

21. Weaver M. J., Harris M. B., Strom A. C., Smith R. M., Lhowe D., Zurakowski D., Vrahas M. S.: Fracture pattern and fixation type related to loss of reduction in bicondylar tibial plateau fractures. Injury. 2012. 43. (6): 864-869. https://doi.org/10.1016/i.injury.2011.10.035

22. Zeng Z. M., Luo C. F., Putnis S., Zeng B. F.: Biomechanical analysis of posteromedial tibial plateau split fracture fixation. Knee. 2011. 18. (1): 51-54. https://doi.org/10.1016/j.knee.2010.01.006

\section{Dr. Csonka Ákos}

SZTE Szent-Györgyi Albert Klinikai Központ, Traumatológiai Klinika

6725 Szeged, Semmelweis u. 6. 